Proc. Estonian Acad. Sci. Eng., 2006, 12, 2, 147-155

\title{
The influence of microstructural stiffness changes on the stress concentration factor of porous polymer materials
}

\author{
Daiva Zeleniakiene \\ Department of Mechanics of Solids, Kaunas University of Technology, Kestucio 27, 44025 \\ Kaunas, Lithuania; Daiva.Zeleniakiene@ktu.lt \\ Received 21 October 2005, in revised form 10 January 2006

\begin{abstract}
The numerical finite element analysis was used to determine the stress concentration factor in the microstructure of porous polymer materials as a function of porosity, distribution mode of pores and loading direction under tensile loading. The results show that the lowest stress concentration factor is characteristic for such polymer materials that exhibit the lowest stiffness changes of matrix adjacent zones in their microstructure. Low stiffness changes of matrix adjacent zones are obtained when the porosity value is high, pores are heterogeneous and the longitudinal axis of thin microstrips between the pores form an angle of $45^{\circ}$ with the direction of tensile.
\end{abstract}

Key words: polymer, porosity, distribution mode of pores, microstructure, stress concentration factor, finite element analysis.

\section{INTRODUCTION}

Contemporary porous materials are widely used instead of the monolithic ones because they are cheaper and lighter and exhibit good strength and deformability $\left.{ }^{1}\right]$. These materials and products made of them are ubiquitous in the automotive, aviation, packaging, furniture, sewing and footwear industry $\left[{ }^{1-5}\right]$.

Porous materials are heterogeneous systems with complex microstructure $\left[{ }^{6}\right]$. These systems are diphase composites with a solid matrix and gaseous filler [ [ ${ }^{7}$. They can be made from polymers, metals and ceramics $\left.{ }^{8-12}\right]$. Macromechanical properties of such heterogeneous systems depend not only on the nature of the materials but on their morphology as well $\left[{ }^{12-14}\right]$.

A kind of porous materials is formed by foams or by so-called cellular materials. Although the mechanics of low-density polymeric foams, the porosity of which is commonly higher than 0.8 , has been widely investigated $\left[{ }^{1,7,15-17}\right]$, the 
effect of lower levels of porosity on the mechanical behaviour of polymeric materials is an item that has been poorly treated in the literature $\left[{ }^{18}\right]$. Porous polymers that are not foams, are usually fabricated either by the addition of a second phase with a lower density or by the addition of a blowing agent prior to curing $\left[{ }^{2}\right]$. Such porous polymers typically have bubble (approximately spherical) pores, which may be homogeneous or heterogeneous. The distribution mode of pores usually has a random character, but in certain conditions a periodical pore distribution has been observed $\left[{ }^{14}\right]$.

Some studies were carried out to determine the influence of the specific microstructure on the mechanical behaviour of porous polymer materials $\left[{ }^{2,14}\right]$. However, it is unclear which porosity mode of a polymer material is superior from the point of view of mechanics. The aim of this investigation is to evaluate the influence of the microstructural stiffness, determined by the porosity and distribution mode of pores, on the stress concentration factor of porous polymer materials.

\section{EXPERIMENTAL}

The microstructure of porous polymer materials was analysed using SEM images. The form, density, distribution mode and level of heterogeneity of pores was determined. This analysis showed that a typical porous polymer contains pores, which usually are spherical and dispersed in the matrix. Subject to abovementioned peculiarities of the microstructure, various stiffness variations of matrix adjacent zones can be observed for different porosity modes; although the porosity is the same.

In order to clarify the influence of microstructural stiffness changes on the stress concentration factor of the porous polymer material, numerical analysis was used. Using the finite element code ANSYS, plane models were designed to utilize symmetry and periodicity, assuming that there are no through-the-thickness stresses in the plane. Eight-node quadrilateral PLANE183 (Structural Solid) elements were used. Three types of microstructural models, which differ from each other in the stiffness changes of matrix adjacent zones, were investigated (Fig. 1). Each model was described by a representative volume element (RVE) $\left[{ }^{14}\right]$. Model I was designed with similar pores, which lay in parallel rows with equal distance between them in each direction (Fig. 1a). The diameter of these pores was $d_{1}$. The high microstructural stiffness changes were characteristic for this model. Model II was created on the basis of Model I; additional pores, diameter of which was $d_{2}<d_{1}$, were added into interpore zones, located between pores $d_{1}$ (Fig. 1b). This insertion of additional pores decreased the stiffness of matrix adjacent zones. Model III consisted pores of three sizes that varied according to selected criteria: $d_{3}<d_{2}<d_{1}$ (Fig. 1c). The lowest microstructural stiffness changes were characteristic for Model III. The ratio of pore diameters to the main dimension $L$ of RVE was proportionally changed as follows: $d_{1} / L=0.01-0.20, d_{2} / L=0.02-0.12$, $d_{3} / L=0.02-0.04$. A more detailed description of these models is given in $\left[{ }^{19,20}\right]$. 


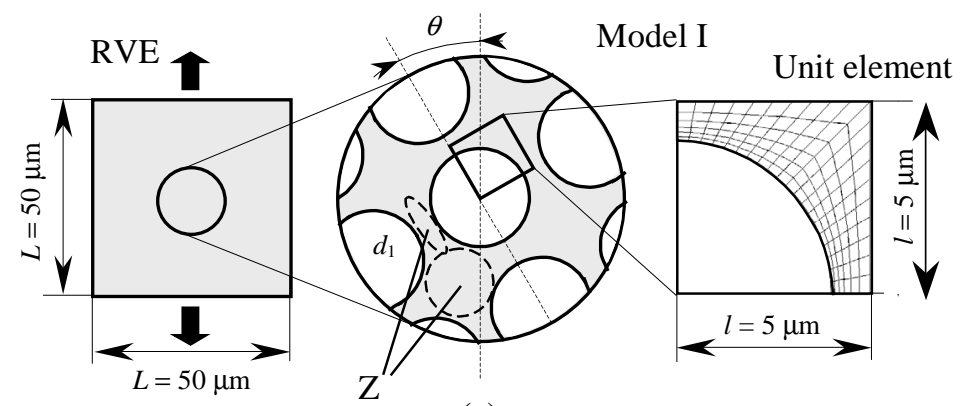

(a)

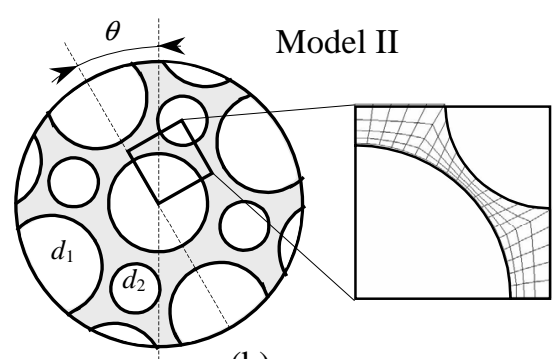

(b)

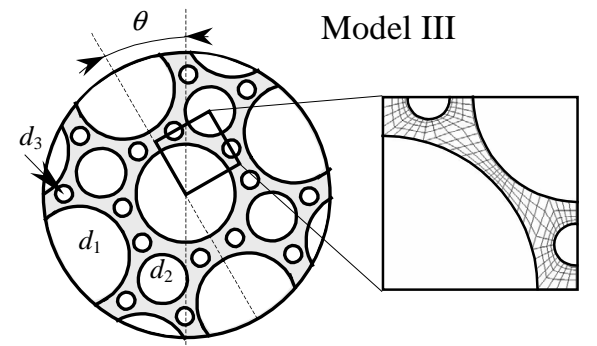

(c)

Fig. 1. Models of the microstructure of porous materials: (a), (b), (c) - distribution modes of pores of Models I, II and III, respectively; $\theta$ - angle of the tension direction; $\mathrm{Z}$ - two matrix adjacent zones: a thin microstrip and a large interpore zone.

In order to investigate the effect of the loading direction on the deformation behaviour, the angle $\theta$ of the tension direction with the principal direction of the unit element is introduced and parametrically varied from 0 to $45^{\circ}$.

The boundary conditions on the macroscopic scale are that the upper surface is shear free with a constant displacement constraint; the bottom surface has constraints on two directions at the point of the symmetry axis of the model and in one direction in other points. The right and left surfaces are assumed to be stress free $\left[{ }^{21}\right]$.

A butadiene-nitrile rubber SKN-40 was used as the matrix material. From the previous investigations it is known that the Mooney-Rivlin equation describes well the mechanical behaviour of this material $\left[{ }^{22}\right]$, thus this equation was used in the present study. The Young modulus of the matrix material is $2.67 \mathrm{MPa}$ and the Poisson ratio is 0.48 .

\section{RESULTS AND DISCUSSION}

The influence of the material porosity value $\gamma$ on the stress concentration factor $K_{\sigma}$ changes for models, as they are loaded by constant strain $\varepsilon=0.2$, is presented in Fig. 2. In the case of Model I, for the low material porosity value 


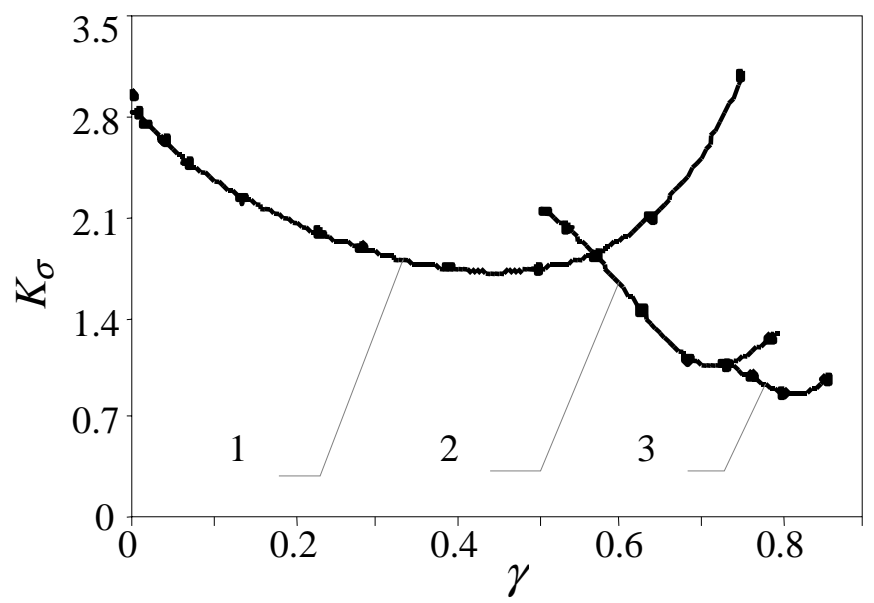

Fig. 2. The dependence of the stress concentration factor $K_{\sigma}$ on the porosity $\gamma$ for Model I (curve 1), Model II (curve 2) and Model III (curve 3) by constant strain $\varepsilon=0.2$.

high stress concentration is observed. As the material porosity increases up to 0.5 , stress concentration factor is considerably reduced. This decrease is determined by the decrease of the deformation force due to the increase of pore diameters and decrease of the volume fraction of the matrix $\left[{ }^{19}\right]$. For porosity higher than 0.5 , independently of the decrease of the deformation force, the stress concentration factor increases monotonously. For this porosity mode, significant changes of the material geometry occur. Between pores in equator zones, only thin material strips are formed but interpore zones are relatively large (Fig. 1a). Due to abrupt stiffness changes of matrix adjacent zones, the stress concentration factor markedly increases.

The curves of stress concentration factors $K_{\sigma}$ of Models II and III have minimums as in the case of Model I. The factors $K_{\sigma}$ decrease as porosity increases and for the higher material porosity value, they insignificantly increase (Fig. 2). The decrease of $K_{\sigma}$ is caused by the decrease of the deformation force as in the case of the Model I. The increase of it is related to the stiffness changes of the matrix adjacent zones (thin microstrips formed between pores $d_{1}$ and $d_{2}$ in the case of Model II and between pores $d_{2}$ and $d_{3}$ in the case of Model III). The stress concentration factor of Model III is the lowest.

The dependence of the stress concentration factor $K_{\sigma}$ of the models on the porosity $\gamma$ and on the angle of loading direction $\theta$ is presented in Fig. 3. When the porosity increases up to 0.5 , the stress concentration factor decreases for all loading directions. The stress concentration factor is the highest when $\theta=0^{\circ}$. In this case the longitudinal axis of microstrips coincides with the direction of the tension. As $\theta$ increases, the stress concentration factor decreases and it is the lowest when $\theta=45^{\circ}$. That can be explained using the scheme presented in Fig. 4 , in which the small element of Model I is shown for two cases: $\theta=0^{\circ}$ and 


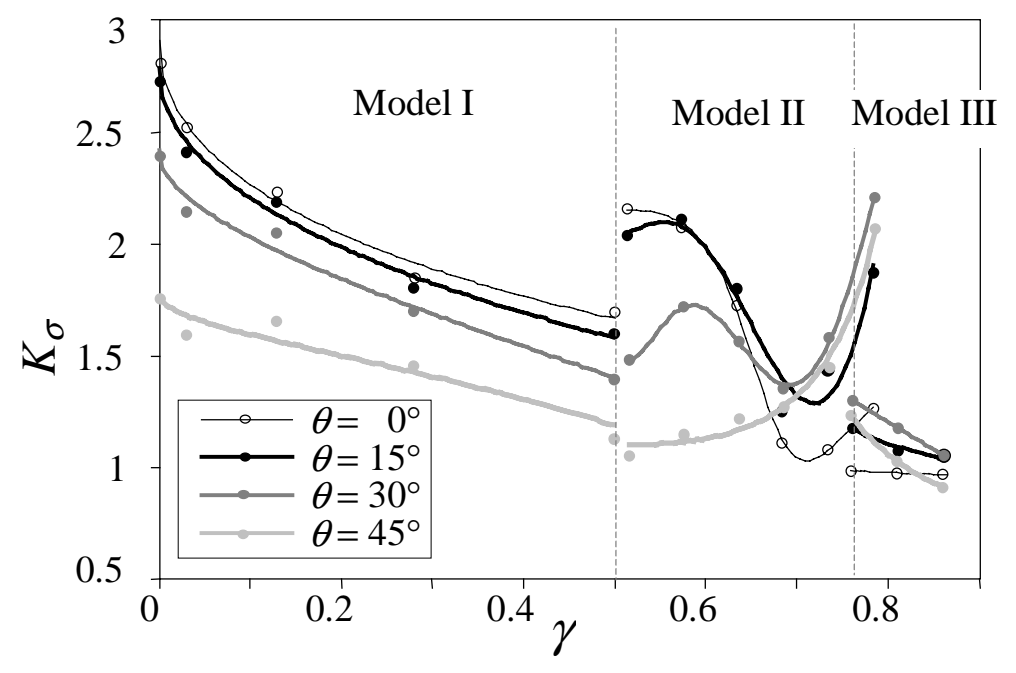

Fig. 3. The dependence of the stress concentration factor $K_{\sigma}$ on the porosity $\gamma$ and on the angle of the tension direction $\theta$ for Models I, II and III when they are loaded by constant strain $\varepsilon=0.2$.
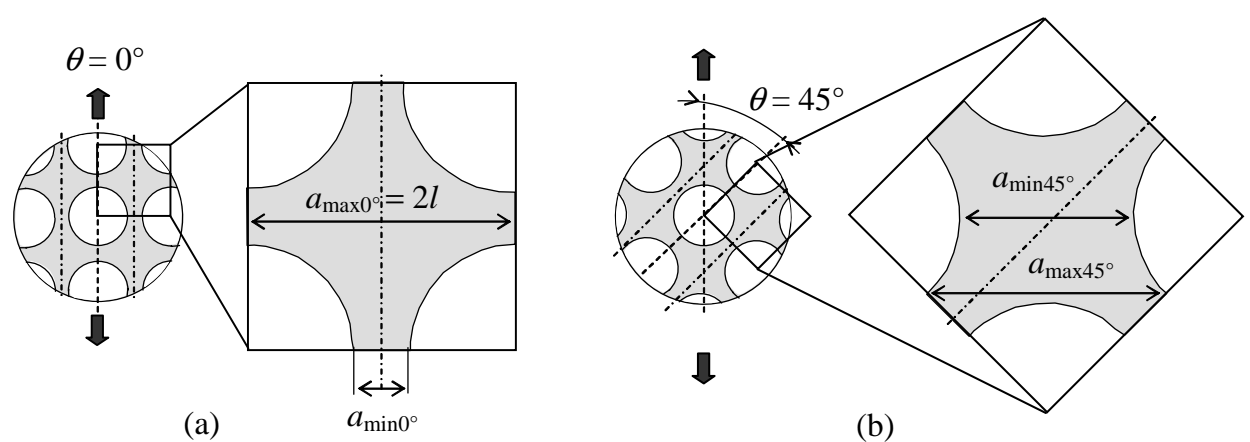

(b)

Fig. 4. Small element of Model I in two cases: (a) $\theta=0^{\circ}$, (b) $\theta=45^{\circ}$.

$\theta=45^{\circ}$. The maximal and minimal lengths of the cross-sections of the elements can be written as

$$
\begin{aligned}
a_{\max 0^{\circ}} & =2 l, \\
a_{\min 0^{\circ}} & =2 l-d_{1}, \\
a_{\max 45^{\circ}} & =2.83 l-0.705 d_{1}, \\
a_{\min 45^{\circ}} & =2.83 l-d_{1} .
\end{aligned}
$$

From Eqs. (1) to (4) follows 


$$
\begin{gathered}
a_{\max 0^{\circ}}-a_{\min 0^{\circ}}=d_{1}, \\
a_{\max 45^{\circ}}-a_{\min 45^{\circ}}=0.295 d_{1} .
\end{gathered}
$$

From Eqs. (5) and (6) follows that the difference of cross-section dimensions of the elements at $\theta=0^{\circ}$ is about three times higher than at $\theta=45^{\circ}$. Since the tensile stiffness depends on the dimensions of the cross-section, it is clear that Model I has the highest tensile stiffness when $\theta=0^{\circ}$ and the lowest difference when $\theta=45^{\circ}$.

Therefore if the longitudinal axis of thin microstrips is parallel to the direction of the tensile, the stress concentration factor is the highest. If the angle between microstrips and the direction of tensile is equal to $45^{\circ}$, the stress concentration factor is the lowest.

In the case of Model II, two kinds of microstrips are formed. One of them is the same as in the Model I, formed between pores $d_{1}$. Other microstrips are formed between pores $d_{1}$ and $d_{2}$ and the angle between their longitudinal axis and tension direction by $\theta=0^{\circ}$ is equal to $45^{\circ}$. Thus the stress concentration factor of Model II depends on the microstrips orientation with respect to the load direction and on the thickness of microstrips. In the case of lower porosity $(\gamma=0.51-0.63)$ Model II exhibits very small pores $d_{2}$. The thinner are the microstrips formed between pores $d_{1}$, the bigger is their influence on stress concentration. Therefore in this case the stress concentration factor is the highest when $\theta=0^{\circ}$ and the lowest when $\theta=45^{\circ}$ like in the Model I. In the case of higher porosity $(\gamma=0.68-0.79)$, the thinner are the microstrips formed between pores $d_{1}$ and $d_{2}$ the higher is their influence on the stress concentration factor. As the angle $\theta$ increases, the thin strips between pores $d_{1}$ and $d_{2}$ are oriented in the direction of tension and the stress concentration factor increases. However, the influence of the loading direction on the stress concentration factor of Model III is low as compared to Models I and II, due to low microstructural stiffness changes characteristic to this model. If in the case of Model II the maximal difference of stress concentration factors is about $50 \%$, in the case of Model III this difference is equal to $16 \%$.

In order to investigate non-linear behaviour of the models in the case of large deformations, the dependence of the stress concentration factor on the stiffness changes, model type, porosity and strain was determined (Fig. 5).

It is seen that stress concentration factors of all models increase as the strain increases. In the case of low strain $(\varepsilon=0.2)$ the stress concentration factor of Model I is significantly higher than that of Models II and III. The same result was obtained in the case of the linear relationship (Fig. 2). For large deformations $(\varepsilon=1.4)$ the stress concentration factor of Model I is considerably higher than that of Model III. It follows that if the distribution mode of pores of a polymer material is similar to that of Model III, the strength of the material is significantly higher than that of the polymer material with distribution mode of pores according to Model I. 


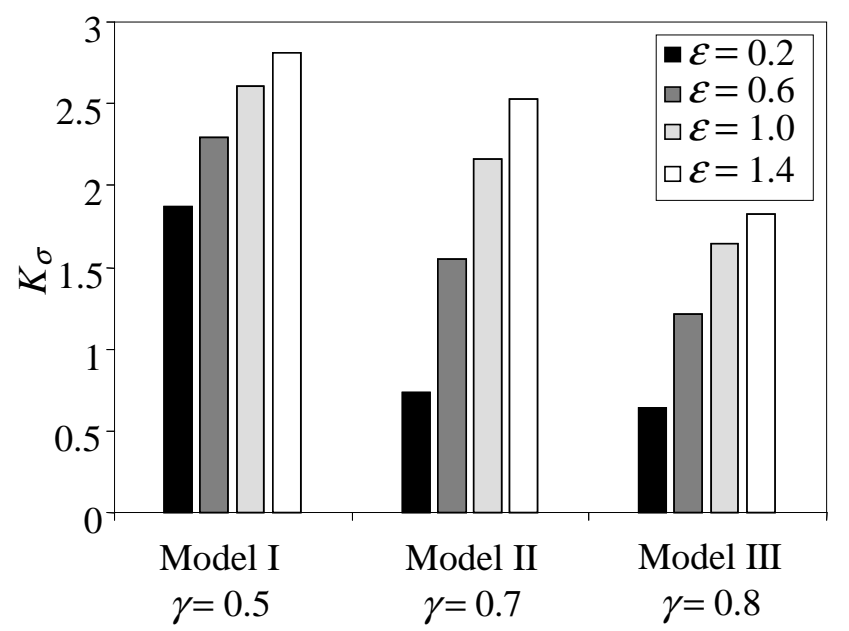

Fig. 5. The dependence of the stress concentration factor $K_{\sigma}$ on the strain $\varepsilon$ for Models I, II and III.

\section{CONCLUSIONS}

1. The stress concentration factor of porous polymer materials loaded by constant strain $(\varepsilon=0.2)$ depends on the porosity and on the distribution mode of pores. It was established that by small and rare pores the stress concentration factor is high $\left(K_{\sigma} \approx 3\right)$. In the case of low strains and high porosity $(\gamma \geq 0.5)$, the stress concentration factor is low if stiffness changes of the matrix adjacent zones are smooth.

2. The value of the stress concentration factor depends on the orientation of the matrix microstrips with respect to loading direction and on the stiffness changes of the matrix adjacent zones. If the longitudinal axis of thin microstrips is parallel to the direction of the tensile, the stress concentration factor is the highest. If the angle between microstrips and the direction of tensile is equal to $45^{\circ}$, the stress concentration factor is the lowest.

3. In all the investigated cases of the strain, the stress concentration factor is the lowest in such porous polymer materials that exhibit the lowest stiffness changes of the matrix adjacent zones.

\section{REFERENCES}

1. Gibson, L. J. and Ashby, M. F. Cellular Solids: Structure and Properties. Cambridge Univ. Pr., Cambridge, 1997.

2. Everett, R. K., Matic, P., Harvey II, D. P. and Kee, A. The microstructure and mechanical response of porous polymers. Mat. Sci. Eng. A, 1998, 249, 7-13.

3. Park, C. and Nutt, S. R. Strain rate sensitivity and defects in steel foam. Mat. Sci. Eng. A, 2002, 232, 358-366. 
4. Thomas, T., Muhfuz, H., Carlsson, L. A., Kanny, K. and Jeelani, S. Dynamic compression of cellular cores: temperature and strain rate effects. Compos. Struct., 2002, 58, 505-512.

5. Andrews, E. W. and Gibson, L. J. The influence of cracks-like defects on the tensile strength of an open-cell Aluminum foam. Scr. Mater., 2001, 44, 1005-1010.

6. Roberts, A. P. and Knackstedt, M. A. Structure-property correlations in model composite materials. Phys. Rev. E, 1996, 54, 2313-2328.

7. Mills, N. J., Fitzgerald, C., Gilchrist, A. and Verdejo, R. Polymer foams for personal protection: cushions, shoes and helmets. Compos. Sci. Technol., 2003, 63, 2389-2400.

8. Kakavas, P. A. and Anifantis, N. K. Effective moduli of hyperelastic porous media at large deformation. Acta Mech., 2003, 160, 127-147.

9. Kanny, K., Muhfuz, H., Carlsson, L. A., Thomas, T. and Jeelani, S. Dynamic mechanical analyses and flexural fatigue of PVC foams. Compos. Struct., 2002, 58, 175-183.

10. Andrews, E. W., Huang, J.- S. and Gibson, L. J. Creep behavior of a closed-cell Aluminum foam. Acta Mater., 1999, 47, 2927-2935.

11. Ruan, D., Lu, G., Chen, F. L. and Siores, E. Compressive behaviour of Aluminum foams at low and medium strain rates. Compos. Struct., 2002, 57, 331-336.

12. Roberts, A. P. and Garboczi, E. J. Elastic properties of model porous ceramics. J. Amer. Ceram. Soc., 2000, 83, 3041-3058.

13. Roberts, A. P. and Garboczi, E. J. Elastic moduli of model random three-dimensional closedcell cellular solids. Acta Mater., 2001, 49, 189-197.

14. Kouznetsova, V., Brekelmans, W. A. M. and Baaijens, F. P. T. An approach to micro-macro modeling of heterogeneous materials. Comp. Mech., 2001, 27, 37-48.

15. Mills, N. J. and Gilchrist, A. Modeling the indentation of low density polymer foams. Cell. Polym., 2000, 19, 389-412.

16. Mills, N. J. and Zhu, H. X. The high strain compression of closed-cell polymers foams. J. Mech. Phys. Solids, 1999, 47, 669-695.

17. Zhu, H. X. and Mills, N. J. Modelling the creep of open-cell polymer foams. J. Mech. Phys. Solids, 1999, 47, 1437-1457.

18. Danielsson, M., Parks, D. M. and Boyce, M. C. Constitutive modeling of porous hyperelastic materials. Mech. Mater., 2004, 36, 347-358.

19. Zeleniakiene, D., Kleveckas, T., Liukaitis, J. and Fataraite, E. The influence of porosity value and mode on soft materials behaviour. Mater. Sci. (Medziagotyra), 2003, 9, 201-205.

20. Zeleniakiene, D., Kleveckas, T., Liukaitis, J. and Marazas, G. The influence of porosity on stress and strain state of porous polymer materials. Mater. Sci. (Medziagotyra), 2003, 9 , 358-362.

21. Zeleniakiene, D., Kleveckas, T. and Liukaitis, J. The effect of loading direction and pores distribution mode on porous polymer material stress concentration. Mater. Sci. (Medziagotyra), 2005, 11, 123-128.

22. Zeleniakiene, D. and Griskevicius, P. The influence of pores distribution mode on the stress of porous elastomeric materials in the case of large deformations. Mater. Sci. (Medziagotyra), $2005,11,248-252$.

\section{Mikrostruktuurse jäikuse muutuste mõju poorsete polümeersete materjalide pingekontsentratsiooni tegurile}

\section{Daiva Zeleniakiene}

Poorsete polümeersete materjalide mikrostruktuuri pingekontsentratsiooni teguri kindlakstegemiseks sõltuvalt poorsusest, pooride suuruse jaotusest ja tõmbepingega koormamise suunast on kasutatud lõplike elementide meetodit. On 
näidatud, et väikseim pingekontsentratsiooni tegur on iseloomulik sellistele polümeersetele materjalidele, mille mikrostruktuuri jäikus muutub vähe maatriksi naaberalades. Sellist mikrostruktuuri iseloomustab kõrge poorsus, pooride suuruse heterogeenne jaotus ja pooridevaheliste õhukeste mikroribade pikitelgede nurk $45^{\circ}$ tõmbepingete suuna suhtes. 